\title{
E-learning Competencies of the Lecturers at Koya University and its Relationship with Some Variables* (Field Research)
}

\author{
Assis. Prof. Dr. Jabbar Ahmed Abdul-Rahman \\ Curriculum and General teaching methods \\ Dept. of Education and Psychology \\ Koya University / Faculty of Education \\ Koya, Iraq \\ Jabar.ahmed@koyauniversity.org
}

\begin{abstract}
Knowing the ability and willingness of lecturers in using technology tasks is a key competency, necessary for learning and teaching. This study aimed to explore the list of e-learning competencies that university lecturers should have, and identify the availability of e-learning competencies of Koya University lecturers. The results revealed that e-learning competencies achieved good level among Koya University teaching staff, and also found no statistically significant differences between male and female lecturers in their e-learning competencies. The faculty of Engineering outweighs both faculties of Humanities and Education, and the faculty of Science and Health outweigh the faculty of Humanities in their e-learning competencies. Additionally, there were no significant differences between lecturers according to academic ranks in their e-learning competencies.
\end{abstract}

Keywords- E-learning, Competencies, Lecturer, Internet, Computer.

* The paper has been presented in the 4th International Scientific Conference of University of Human Development, April, , 2017.

\author{
Dr. Zhwan dalshad Abdullah \\ Curriculum and education \\ Dept. of Clinical Psychology \\ Koya University / Faculty of Science and Health \\ Koya, Iraq \\ zhwan.dalshad@koyauniversity.org
}

\section{INTRODUCTION}

Technology became a major turning point in the history of the educational field, it provides an enormous spectrum of possibilities for new approaches to teaching and hence for learning across the curriculum (Pierce, Stacey, \& Barkatsas, 2007; Yin, 2010).

Throughout the world there is awareness of the fundamental role of new information and communication technologies in the field of education. Moreover, technology is a significant factor in enhancing the quality of education and learning, by making it more accessible to people (Bakr, 2011; Hismanoglu, 2012). In fact, technology can have positive benefits but they depend on how the technology is used and how it changes the nature of the education, which means the challenge rests with educator to effectively integrate into appropriate places throughout the curriculum(Barron, 2002; Gura \& Percy, 2005).

Yusuf and Balogun (2011) believed that, the use of information and communication technology as a tool for enhancing students' learning, teachers' instruction, and as catalyst for improving access to quality education in formal and non-formal settings become a necessity. Additionally, Knowlton and Simms (2010) stated that many ways exist for integrating computers into higher education courses. For instance, integrating productivity software such as word processing, spreadsheets, and databases into traditional courses can provide useful learning experiences for students.

People can learn from computer software and the Internet and as such there is a pedagogic rationale for using IT in education as a supplement to the traditional learning process. For this reason, many colleges and universities used multimedia technologies in instruction for the purpose of enhancing teaching and learning productivity (Ford, 2012). Based on the prior studies conducted by (Sisco, Woodcock, Eady, 2015; Starcic, 2010; Soma, 2014; Alvarez et al., 2009) instructors are becoming accountable for building e-learning skills into their repertoires. Roughly speaking, technology has become an integral part of higher education, enabling students to access information rapidly. For that reason, recently the Ministry of Higher Education in Kurdistan Regional-Iraq has actively encouraged lecturers to integrate technology into the curriculum and pursue technologyenhanced learning activities to cultivate information technology literacy at the universities (Abdullah et al., 2016). 
Technology in education can involve all sorts of issues related to capacity and complexity. In any e-learning project, information technology will become an important stakeholder and its support is therefore critical (Stockley 2006).

E-learning is the delivery of a learning, training or education program by electronic means. It provides a variety of equipment for the perfect blended learning environment. E-learning involves the use of a computer or electronic device (e.g. a mobile phone, computers, internet, CD-Roms, projection TVs, word processors, image graphic software, email, and telephone) in some way to provide training, educational or learning material (Stockley, 2006; Bidarian et al., 2011; Song \& Kang, 2012).

This article is attempting to clarify the university lecturer roles and competencies in e-learning, to know their level of knowledge, accessing, managing, using, and designing software and multimedia education. Competence has been defined by Spector and de la Teja (2001) as the "state of being well qualified to perform an activity, task or job function" and also competency as "the way that a state of competence can be demonstrated to the relevant community" (p. 2).

Prior studies offered insights into lecturer's participations and competencies in e-learning such as, Omari (2009) who found that generally teacher's e-learning competence was a moderate level. Differences were found in their competence in managing computers in favor of scientific field teachers; also the old lecturers' competence level was lower than new lecturers.

Likewise, Sallam (2011) indicated that the level of computer and internet access were high among lecturers. The study also showed differences in accessing, managing, and IT knowledge among lecturers in favor of scientific field of study. In addition, the level of lecturer's competence who participated in more than three training courses was higher than who have never attended any courses before. Mihhailova (2006) found that the main problem areas for lecturers related to e-learning are: lack of time, lack of interest/motivation, lack of co-operation, and compensation system that do not take into account the specifics of elearning, and lecturers are concerned about the quality of teaching in a virtual environment. The most problematic of them appear to be lack of time and inappropriate compensation system. On the other hand, Tomei (2007) stated that other researchers still find that technological resources are misused and abused which can create more problems than good. However, user expectations and perceived outcomes of technology are not well understood (Parker, Bianchi, \& Cheah, 2008).

Further analysis finds that the recorded lecture content and the response time to users are the most critical problems in teaching and administration (Lin et al., 2011).

The analysis of the previous literature was found to have mixed results regarding the lecturer's e-learning competencies such as, (Omari 2009; Sallam, 2011; Sisco, Woodcock, Eady, 2015; Starcic, 2010; Soma, 2014; Alvarez et al., 2009) who manifested lecturer's e-learning competencies based on their levels of managing computers, field of the study, IT knowledge, and attending training courses. While, other studies such, Alvarez et al. (2009) stated that, the lecturers e-learning competence do not refer to standards of teacher performance; on the contrary, he emphasized that the notion of socially situated competencies which are derived from the roles and tasks attributed to university teachers in online learning environments, without losing track of the dialectics and integrity of their exercise.

Chang and Kintu (2015) investigated the strengths, weaknesses, opportunities and threats to integrating elearning perceived by academic staff. The researchers found that the lack of capacities in terms of institutional policies, teacher competencies and internal investment constitute the weaknesses and threats for the universities.

Likewise, Baran, Correia, and Thompson (2011) indicated that while research about online teacher roles and competencies guides the development of teacher preparation and training programs, it lacks in terms of addressing the issues of empowerment of online teachers, promoting critical reflection, and integrating technology into pedagogical inquiry. An alternative perspective is suggested that considers teachers as adult learners who continuously transform their meaning of structures related to online teaching through a continuous process of critical reflection and action.

Moreover, Malufu, Muchemwa, and Malufu (2016) showed that lecturers generally believed they were computer literate but using e-learning may not be beneficial to their students. They also found that lecturers lacked motivation and institutional support; they perceived it difficult to use elearning in their subjects and they had a negative attitude towards it. Further finding showed that lecturer's competence and nature of the subject have great influence on the adoption of e-learning by lecturers at the universities.

Ochogo et al. (2014) concluded that the under-funding was a key factor constraining access to computers at the workplace, reliable internet connectivity and timely technical support, all of which significantly associated with lecturers' preparedness for e-learning.

In addition, Long, Ibrahim, and Kowang (2014) believed that, although it is possible to assess a competence from the performance of a lecturer, it is not necessary that all competencies of a lecturer have the same extent of knowledge and skill.

Globally disseminated, competencies have become highly valued by educators and educational institutions throughout the world (Gulbahar \& Kalelioglu, 2015).

The significance of this study is to determine the competencies of e-learning that must be met the teaching staff at Koya University. Also to find out what the university teaching staff needs from the competencies of e-learning to be included within the university courses and training activities to improve their performance.

However, there is limited research on lecturer's elearning competencies; there is a need to look at the level of lecturer's competence in Kurdistan universities generally. Thus, to improve lecturer's e-learning competence, there is a need to ensure that the information systems used by the universities are always readily accessible.

\section{Methodology}

In this study the descriptive and correlative methodology used because it is commensurate with the nature of this research. 


\subsection{Purpose of Study}

This study aimed to concentrate on lecturers' e-learning competencies at Koya University. Specifically, the study examined the list of e-learning competencies that university lecturers should have. It also attempts to identify the availability of e-learning competencies of Koya University lecturers.

\subsection{Research Questions:}

1. What are the e-learning competencies that Koya university lecturers should have?

2. What is the level of e-learning competencies among Koya university teachers?

3. Are the e-learning competencies changed according to categories of Gender among Koya University lecturers?

4. Are the e-learning competencies changed according to categories of Faculty among Koya University lecturers?

5. Are the e-learning competencies changed according to categories of Academic Ranks among Koya University lecturers?

6. Are the e-learning competencies changed according to categories of Academic Degree among Koya University lecturers?

\subsection{Sample size}

This study was conducted at Koya University. It was limited to teaching staff in all four faculties (Engineering, Science and Health, Human Science, Education). The respondents of this study were 120 from 457 lecturers in all four faculties; as it is summarized in Table 1, the sample was voluntarily selected.

Table 1: The sample size of the study

Research Sample

Faculties

$\begin{array}{ccc}\begin{array}{c}\text { The } \\ \text { number } \\ \text { taken }\end{array} & \begin{array}{c}\text { The percentage } \\ \text { derived from the } \\ \text { Community }\end{array} & \begin{array}{c}\text { The sample } \\ \text { percentage }\end{array} \\ 31 & 25.41 & 25.8\end{array}$

\begin{tabular}{cccc} 
Engineering & 26 & 23.63 & 21.7 \\
S\&H & 12 & 19.04 & 10.0 \\
HS & 51 & 31.48 & 42.5 \\
Ed & 120 & $\% 26.26$ & $\% 100.0$ \\
Total & & & \\
\hline
\end{tabular}

\subsection{Research Instrument}

The instrument was developed by the researchers in order to examine lecturers' e-learning competencies. It was consisting of 45 items used a Likert scale from 0 (unversed), 1 (low), 2 (good), 3 (medium), 4 (high), and four hypothesized dimensions (The competencies of the elearning knowledge) six items, (Competence in commanding and using computer) 13 items, (Competence in commanding Internet) 18 items, and (Competence of software design and multimedia education) seven items. These dimensions are representing the level of e-learning competencies. This questionnaire was developed based on the established literature such as (Al-Mehmadi, 2012; Omari, 2009; Barbeite and Weiss 2004; Durndell and Haag 2002; Murphy, Coover, and Owen 1989) to develop the elearning competencies questionnaire by modifying, changing and adding the items to be relevant in measuring the four dimensions of e-learning competencies.

\subsection{Validity and the Reliability}

\subsubsection{Virtual Validity}

The questionnaire was validated by specialists and experts; they recommended making corrections to some words and checked for ambiguity, confusion and any unexpected questions in the instruments (Appendix 1). As a result, 4 items were reduced from the e-learning competencies questionnaire and 41 items remained. First dimension: the competencies of the e-learning knowledge, became (5) items, second dimension: competence in commanding and using computer, become (12) items, third dimension: competence in commanding Internet, became (18) items, fourth dimension: competence of software design and multimedia education, became (6) items.

\subsubsection{Internal consistency Validity}

In order to find internal consistency validity, the researchers depended on the Statistical Package for Social Sciences (SPSS) to find out a correlation coefficient (Spearman) between the items and the scale as a whole, a correlation between the items and their fields, and a correlation between the fields with the scale. The results showed that all the items were correlated with their fields and the scale. The fields also correlated with the scale strongly and they were statistically significant at the 0.01 level. Table 2 ; is only showing the correlation between the dimensions (fields) with the scale. 
Table 2: Spearman correlation between the Dimensions and the scale

\begin{tabular}{lll}
\hline Dimensions & Spearman Correlation & Sig. \\
\hline First & $0.770^{* *}$ & .000 \\
Second & $0.898^{* *}$ & .000 \\
Third & $0.948^{* *}$ & .000 \\
Fourth & $0.879^{* *}$ & .000 \\
\hline
\end{tabular}

\subsubsection{Reliability}

The reliability for the 41 items was established at 0.961 , using the Cronbach alpha, indicating high internal consistency, see Table 3.

Table 3: Cronbach's Alpha reliability

\begin{tabular}{ccc}
\hline Value of Cronbach's alpha & Items & sample \\
\hline 0.961 & 41 & 100 \\
\hline
\end{tabular}

\subsection{Research Procedures and Data analysis}

After the distribution of 457 questionnaires; only 120 questionnaires were valid $26.26 \%$, including 31 from engineering, 26 from science and health, 12 from human science, and 51 from education. For the data analysis; SPSS technique was applied in this study, which was the arithmetic mean, and standard deviation, Cronbach's Alpha, Spearman Correlations, Independent Samples t-Test, OneWay ANOVA, and Equal Variances Assumed: Scheffe.

\section{Findings}

1- To answer the first research question: What are the e-learning competencies that Koya university lecturers should have? The answer of this question has been achieved, as it stated in the procedures of this research.

2- To answer the second research question: What is the level of e-learning competencies among Koya university lecturers? The researchers find the Asthmatic Mean of the sample; it was 125.37 , as summarized in Table 4.

Table 4: The Asthmatic Mean of the sample

\begin{tabular}{ccccc}
\hline & N & Mean & $\begin{array}{c}\text { Std. } \\
\text { Deviation }\end{array}$ & $\begin{array}{c}\text { Std. } \\
\text { Error } \\
\text { Mean }\end{array}$ \\
\hline scale & 120 & 125.3750 & 25.72905 & 2.34873 \\
\hline
\end{tabular}

To determine the total scores taken on the scale at every level we multiply the (grades given to any alternatives) by (total number of items of the scale 41) shown in Table 5.
Table 5:

\begin{tabular}{lccccc}
\hline & $\begin{array}{c}\text { unverse } \\
\text { d }\end{array}$ & \multicolumn{4}{c}{ capable at the level of } \\
& & & & & \\
& 0 & 1 & 2 & 3 & 4 \\
& incapabl & low & medium & good & high \\
& e & & & & \\
& & & & & \\
Total &. & 41 & 82 & 123 & 164 \\
scores & & & & & \\
taken on \\
the scale \\
(41) \\
items
\end{tabular}

Therefore, we can identify the availability of e-learning competencies of Koya University teachers by comparing the arithmetic mean of the sample with the following Scheme:

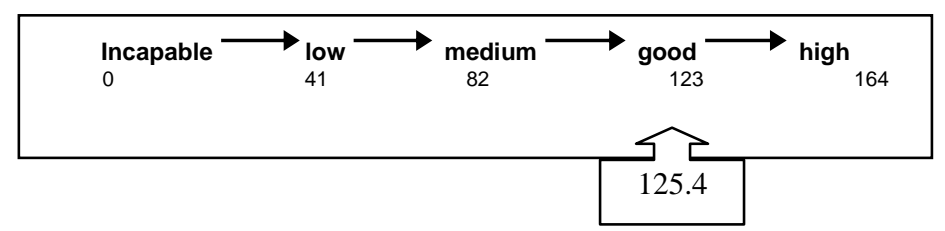

We conclude that the arithmetic mean of the sample was higher than the good level competencies in e-learning.

3- In answering the third research question: Are the e-learning competencies changed according to categories of gender among Koya University lecturers? This research question was tested by using

Independent Samples t-Test technique, they find the mean of the male which was 123.86 , whilst the standard deviation was 24.6, the mean of the female was 129.36 , whilst the standard deviation was 28.5 , the degree of freedom was 118 , the value of (t) was 1.046, which was not statistically significant at the level 0.05 , as shown in Table 6 . 
Table 6:

\begin{tabular}{|c|c|c|c|c|c|c|}
\hline Groups & $\mathrm{N}$ & Mean & $\begin{array}{l}\text { Std. } \\
\text { Deviatio } \\
\mathrm{n}\end{array}$ & $t$ & d.f. & $\begin{array}{l}\text { Sig. } \\
2- \\
\text { tailed } \\
0.05\end{array}$ \\
\hline $\mathrm{M}$ & 87 & 123.86 & 24.6 & 1.046 & 118 & .298 \\
\hline $\mathrm{F}$ & 33 & 129.36 & 28.5 & & & \\
\hline
\end{tabular}

4- $\quad$ In answering the fourth research question: Are the e-learning competencies changed according to categories of Faculty among Koya University lecturers? This research question was tested by using

ANOVA, the value of $(\mathrm{F})$ was 6.043 , which was statistically significant at the level 0.05 , as shown in Table 7.

Table 7: ANOVA

\begin{tabular}{crrrrr}
\hline & $\begin{array}{c}\text { Sum } \\
\text { of }\end{array}$ & df & Mean & F & Sig. \\
& Squar & & \\
& \multicolumn{1}{c}{ es } & & $\mathrm{e}$ & & \\
Betwee & \multicolumn{1}{c}{10646} & 3 & 3548. & 6.0 & .001 \\
$\mathrm{n}$ & .962 & & 987 & 43 & \\
Groups & & & & & \\
Within & 68129 & 11 & 587.3 & & \\
Groups & .163 & 6 & 20 & & \\
Total & 78776 & 11 & & & \\
& .125 & 9 & & & \\
\hline
\end{tabular}

To show the differences between the faculties, the researchers used Scheffe technique, which showed that the faculty of Engineering outweighs both faculties of Humanities and Education, and the faculty of Science and Health outweigh the faculty of Humanities according to their e-learning competencies, as shown in Table 8 below:

\section{Table 8: Scheffe}

\begin{tabular}{|c|c|c|c|}
\hline (I) faculty & (J) faculty & $\begin{array}{c}\text { Mean } \\
\text { Difference } \\
(\mathrm{I}-\mathrm{J})\end{array}$ & Sig. \\
\hline \multirow[t]{4}{*}{ Engineering } & Science and & .66625 & 1.00 \\
\hline & Health & & 0 \\
\hline & Human Science & $27.43548^{* 1}$ & .014 \\
\hline & Education & $15.70019^{*}$ & .049 \\
\hline \multirow{4}{*}{$\begin{array}{c}\text { Science } \\
\text { and Health }\end{array}$} & Engineering & -.66625 & 1.00 \\
\hline & & & 0 \\
\hline & Human Science & $26.76923^{*}$ & .022 \\
\hline & Education & 15.03394 & .091 \\
\hline Human & Engineering & $-27.43548^{*}$ & .014 \\
\hline \multirow[t]{3}{*}{ Science } & Science and & $-26.76923^{*}$ & .022 \\
\hline & Health & & \\
\hline & Education & -11.73529 & .519 \\
\hline \multirow[t]{4}{*}{ Education } & Engineering & $-15.70019^{*}$ & .049 \\
\hline & Science and & -15.03394 & .091 \\
\hline & Health & & \\
\hline & Human Science & 11.73529 & .519 \\
\hline
\end{tabular}

5. In answering the fifth research question: Are the e-learning competencies changed according to categories of Academic Ranks among Koya University lecturers? This question was tested by using ANOVA of SPSS, the value of (F) was .644, which was non- statistically significant at the level 0.05 , which is mean the e-learning competencies not changed according to categories of Academic Ranks among Koya University lecturers as shown below at Table 9 . 
Table 9: ANOVA

\begin{tabular}{crrcrr}
\hline & $\begin{array}{c}\text { Sum } \\
\text { of }\end{array}$ & df & Mean & F & Sig. \\
& Squar & & Squar & & \\
& es & & & & \\
Betwee & 1290. & 3 & 430.2 & .644 & .588 \\
n & 7 & & & & \\
Groups & & & & & \\
Within & 77485 & 116 & 667.9 & \\
Groups & .3 & & & \\
Total & 78776 & 119 & & \\
& .1 & & & \\
\hline
\end{tabular}

6. In answering the sixth research question: Are the e-learning competencies changed according to categories of Academic Degree among Koya University lecturers? This research question was tested by using technique Independent Samples tTest, they find the mean of the $\mathrm{PhD}$ which was 122.82 , whilst the standard deviation was 24.56 , the mean of the MSc was 127.2, whilst the standard deviation was 26.55 , the degree of freedom was 118 , the value of (t) was .919 , which was no statistically significant at the level 0.05 , as shown below at Table 10 .

Table 10:

\begin{tabular}{lllllll}
\hline $\begin{array}{l}\text { Acade } \\
\text { mic }\end{array}$ & $\mathrm{N}$ & Mean & $\begin{array}{l}\text { Std. } \\
\text { Deviation }\end{array}$ & $\mathrm{t}$ & d.f. & $\begin{array}{l}\text { Sig. 2- } \\
\text { tailed } \\
\text { Degre }\end{array}$ \\
$\mathrm{e}$ & & & & & & $(0.05)$ \\
& & & & & & \\
\hline $\mathrm{PhD}$ & 50 & 122.82 & 24.56 & .919 & 118 & .36 \\
& & & & & & \\
MSc & 70 & 127.2 & 26.55 & & & \\
& & & & & &
\end{tabular}

\section{DISCUSSIONS AND CONCLUSIONS}

The purpose of this study was to determine the list of elearning competencies that university lecturers should have, and also to identify the availability of e-learning competencies of Koya University lecturers. Based on the findings, e-learning competencies achieved good level among Koya University teaching staff. This finding is consistent with Sallam (2011) which indicated that, the computer and internet access was in a high level among lecturers, also Malufu, Muchemwa, and Malufu (2016), who showed that lecturers generally believed they were computer literate. This result may be attributed to the reason that Koya University has enable their faculty members to achieve competences of e-learning and opened many training courses to them, also made their teachers communicate with their students through their portfolio. Moreover, the university has encouraged them to spread their activities across the web.

In addition, the current study also showed no significant differences between male and female of Koya University teaching staff; according to their e-learning competence at the level of 0.05 . This result revealed that the female lecturers at Koya University have the same level comparing with the male in their e-learning competencies; they are making use of their maximum potential efforts, so as not to lag behind in e-learning competencies.

In this current study, appeared that, the faculty of Engineering outweighs both faculties of Humanities and Education, and the faculty of Science and Health outweigh the faculty of Humanities according to their e-learning competencies. Previous studies were consistent with this study such as (Omari 2009; Sallam, 2011; Sisco, Woodcock, Eady, 2015). This result may be attributed to the reason that both Faculties of Engineering and Science are purely scientific, and lecturers in those faculties need daily contact with computer and dealing with e-learning more than the lecturers in faculties of humanity and social science.

Moreover, there are no significant differences between Koya University lecturers according to their academic ranks (Professors, Assistant Professors, Lecturer, and Assistant Lecturer) at their e-learning competence at level of 0.05 . This result might be due to that teachers with academic rank holds (Professor and Associate Professor) have been able to control the competencies of e-learning, however, holders of the new academic rank (lecturer and assistant lecturer) also have been able to control the competencies of e-learning because the majority of them have completed their studies at universities in foreign countries, and there have been forced to mastery of competencies of e-learning.

The findings of this study provide evidence of lecturer's elearning competencies at Koya University, and contribute to our understanding of the ability and the willingness of lecturers at Koya University in their use of e-learning, which showed to be in a good level.

\section{RECOMMENDATIONS:}

Based on the results of this study, the researchers recommended the officials at the university beside the Ministry of Higher Education and Scientific Research, and draw their attention to bear in mind the following points:

1. Focus on e-government.

2. Make all correspondence, instruction and activities in universities and the ministry electronically.

3. Opening intensive ongoing courses for the university teachers to enable them to improve their e-learning competencies. 
4. Pay particular attention to college's staff of education, humanities and social sciences faculties to enable them to improve their e-learning competences.

\section{SUGGESTIONS}

1. Conducting a similar study on the other universities.

2. Conducting a similar study to compare between several universities in the region, taking into account current research results.

3. Conducting a study which proposes an approach or curriculum of e-learning competences in order to be taught at the (PhD or MSc) degree at the university.

\section{References}

[1] A., Guasch, T. \& Espasa, A. (2009). University Teacher Roles and Competencies in Online Learning Environments: A Theoretical Analysis of Teaching and Learning Practices. European Journal of Teacher Education, 32(3), 321-336

[2] Abdullah, Zhwan Dalshad, Azidah Abu Ziden, Rhimi Chi Aman, and Khalid Ismail Mustafa. "Students" Attitudes Towards Information Technology and the Relationship with Their Academic Achievement." Contemporary Educational Technology 6, no. 4 (2016): 338-54.

[3] Al-Mehmadi, Rania Hamed Daxil. "The Levels of Arabic Language Female Teachers Ability in Efficiencies of Elearning to Teach It in a High School in the Holy Capital." UMM AL-QUARA, 2012.

[4] Alvarez, I., T. Guasch, and A. Espasa. "University Teacher Roles and Competencies in Online Learningenvironments: A Theoretical Analysis of Teaching and Learningpractices." European Journal of Teacher Education 23, no. 3 (2009): 321-36.

[5] Bakr, Samira M. "Attitudes of Egyptian Teachers Towards Computers." CONTEMPORARY EDUCATIONAL TECHNOLOGY 2, no. 4 (2011): 308-18.

[6] Baran, Evrim, Ana Paula Correia, and Ann Thompson. "Transforming Online Teaching Practice: Critical Analysis of the Literature on the Roles and Competencies of Online Teachers." journal of Distance Education 32, no. 3 (2011): 421-39.

[7] Barbeite, Francisco G., and Elizabeth M. Weiss. "Computer Self-Efficacy and Anxiety Scales for an Internet Sample: Testing Measurement Equivalence of Existing Measures and Development of New Scales." Computers in Human Behavior 20 (2004): 1-15.

[8] Barron, Ann E. Technologies for Education: A Practical Guide. United States of America: Libraries Unlimited, 2002.

[9] Bidarian, Shabnam, soheila Bidarian, and Amirhosein Mohammad Davoudi. "A Model for Application of Ict in the Process of Teaching and Learning." Procedia Social and Behavioral Sciences 29 (2011): 1032-41.

[10] Durndell, Alan, and Zsolt Haag. "Computer Self Efficacy, Computer Anxiety, Attitudes Towards the Internet and Reported Experience with the Internet, by Gender, in an East European Sample." Computers in Human Behavior 18 (2002): 521-35.

[11] Ford, Edmund H. "Faculty Perceptions of Information Technology and Its Perceived Usefulness at a Public, Urban University in Tennessee." Tennessee State University 2012.
[12] Gulbahar, Yasemin, and Filiz Kalelioglu. "Competencies for E-Instructors: How to Qualify and Guarantee Sustainability." CONTEMPORARY EDUCATIONAL TECHNOLOGY 6, no. 2 (2015): 140-54.

[13] Gerda, Mihhailova. 2006. E-learning as internationalization strategy in higher education: Lecturer's and student's perspective. Baltic Journal of Management 1(3):270-284 . September 2006: DOI: $10.1108 / 17465260610690926 \cdot$ Source: OAI

[14] Gura, Mark, and Bernard Percy. Recapturing Technology for Education: Keeping Tomorrow in Today's Classrooms. United States of America: Scarecrow Education, 2005.

[15] Hismanoglu, Murat. "The Impact of a Curricular Innovation on Prospective Efl Teachers' Attitudes Towards Ict Integration into Language Instruction ". International Journal of Instruction 5, no. 1 (2012): 184201.

[16] Knowlton, Dave S., and Julia Simms. "Computer-Based Instruction and Generative Strategies: Conceptual Framework \& Illustrative Example." Computers in Human Behavior 26, no. 5 (2010): 996-1003.

[17] Lin, Kan Min, Nian-Shing Chen, and Kwoting Fang. "Understanding E-Learning Continuance Intention: A Negative Critical Incidents Perspective." Journal Behaviour \& Information Technology 30, no. 1 (2011): 77-89.

[18] Long, Choi Sang, Zaiton Ibrahim, and Tan Owee Kowang. "An Analysis on the Relationship between Lecturers' Competencies and Students' Satisfaction." International Education Studies 7, no. 1 (2014): 37-46.

[19] Malufu, Khanyisa, Stella Muchemwa, and Siduduziwe Malufu. "A Comparative Study of the Factors Influencing the Adoption of E-Learning by Lecturers at Universities in Bulawayo, Zimbabwe." IOSR Journal of Research \& Method in Education 6, no. 4 (2016): 6473.

[20] Murphy, Christine A., Delphine Coover, and Steven V. Owen. "Development and Validation of the Computer Self-Efficacy Scale." Educational and Psychological Measurement 49 (1989): 893-99.

[21] Ochogo, Nicholas Kut, Charles Mallans Rambo, Joyce Kanini Mbwesa, and Paul Amollo Odundo. "Influence of Institutional Support on Lecturers' Preparedness for E-Learning at the University of Nairobi, Kenya." Chinese Business Review 13, no. 12 (2014): 757-73.

[22] Omari, Ali bin Musa. "E-Learning Competency of High School Teachers in Makhwah Province." Umm Al Qura University, 2009.

[23] Parker, Robyn E., Alison Bianchi, and Tsui Yi Cheah. "Perceptions of Instructional Technology: Factors of Influence and Anticipated Consequences." Educational Technology \& Society 11, no. 2 (2008): 274-93.

[24] Pierce, R., K. Stacey, and Anastasios Barkatsas. "A Scale for Monitoring Students' Attitudes to Learning Mathematics with Technology." Computers and Education 48, no. 2 (2007): 285-300.

[25] Sallam, Marwan Hasan. "The Availability of ELearning Competencies with Faculty Members at the University of Ibb, Yemen." University of IBB, 2011.

[26] Soma, Pillay, and James Reynold. "The Pains and Gains of Blended Learning - Social Constructivist Perspectives." Education \& Training 56, no. 4 (2014): 254-70.

[27] Song, Hae-Deok, and Taehoon Kang. "Evaluating the Impacts of Ict Use: A Multi-Level Analysis with Hierarchical Linear Modeling ". The Turkish Online Journal of Educational Technology 11, no. 4 (2012): 132-40.

[28] Spector, J. M., \& de la Teja, I. (2001). Competencies for online teaching. ERIC Digest. ERIC Clearinghouse on Information and Technology. Syracuse: NY. Retrieved 


$\begin{array}{llll}\text { on } & 15 & \text { May } & 2013\end{array}$
http://www.eric.ed.gov/PDFS/ED456841.pdf.

[29] Starcic, Andreja Istenic. "Educational Technology for the Inclusive Classroom." The Turkish Online Journal of Educational Technology 9, no. 3 (2010): 26-37.

[30] Stockley, Derek. "Building a Successful E-Learning Strategy." E-learning is by no means a panacea and requires extensive tailoring to ensure positive results and strong adoption (2006). Published electronically Februwary. http://www.derekstockley.com.au/articles/ei-magazinefeb-06.pdf.

[31] Tomei, Lawrence A. "Powerpoint Presentations Increase Achievement and Student Attitudes Towards Technology." Information and Communication Technology Education 3, no. 4 (2007): 64-75.

[32] Woodcock, Stuart, Ashley Sisco, and Michelle Eady. "The Learning Experience: Training Teachers Using
Online Synchronous Environments." Journal of Educational Research and Practice 5, no. 1 (2015): 21 34.

[33] Yin, Weijia. "The Effects of Technology on Students' Achievement Motivation in Chinese College English Classes." University at Buffalo, State University of New York, 2010.

[34] Yusuf, Mudasiru O., and Modupe R. Balogun. "StudentTeachers' Competence and Attitude Towards Information and Communication Technology: A Case Study in a Nigerian University." Contemporary Educational Technology 2, no. 1 (2011): 18-36.

[35] Zhu, Chang, and Kintu Justice Mugenyi. "A Swot Analysis of the Integration of E-Learning at a University in Uganda and a University in Tanzania." Technology, Pedagogy and Education 24, no. 5 (2015): $1-19$

\section{Appendix (1)}

\section{The names of the experts who have been consulted about the tool}

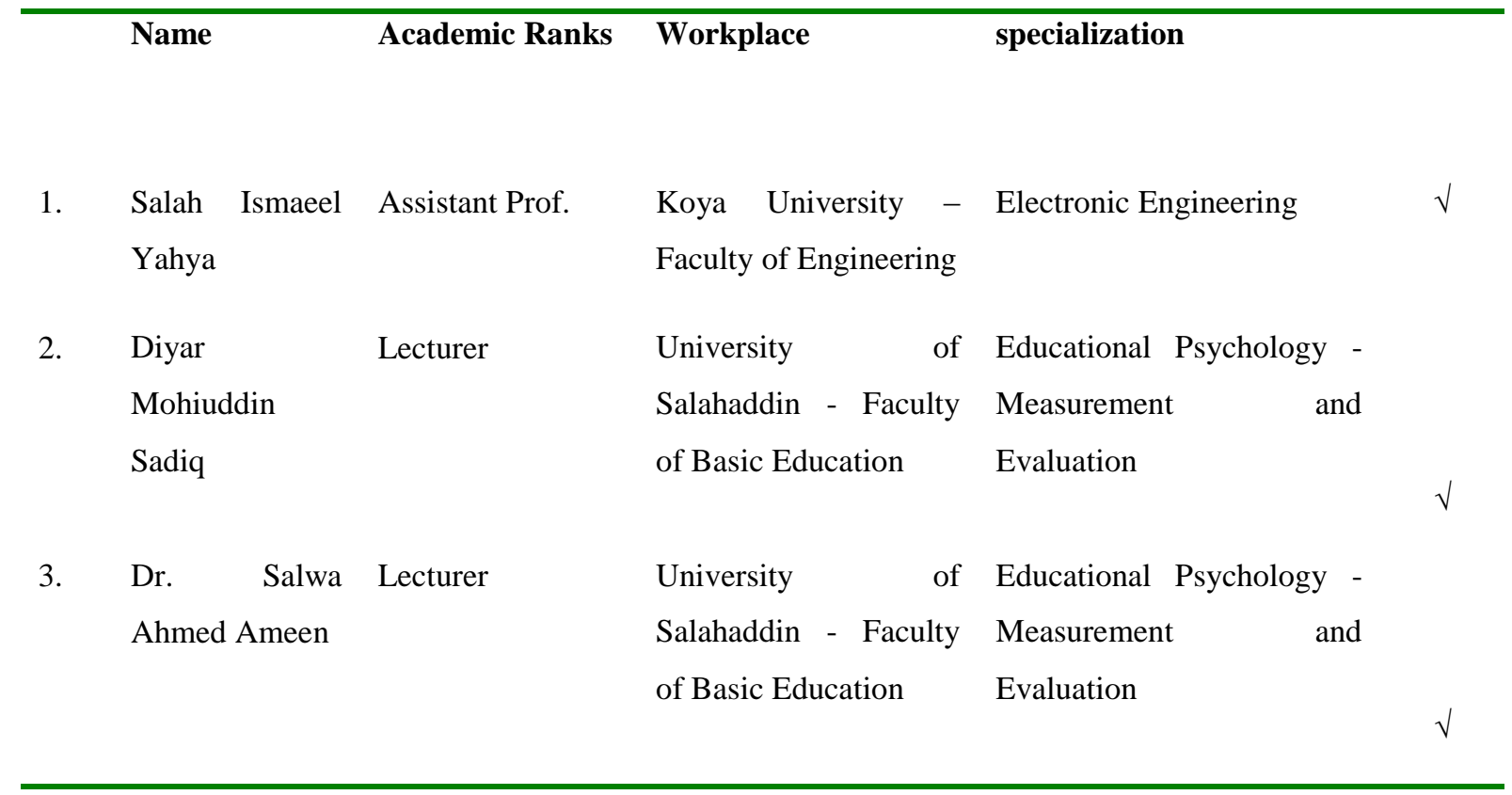

